\author{
Gabriela da Costa Silva \\ Arquiteta e urbanista, doutoranda em planejamento e gestão \\ ambiental do Programa de Pós-graduação em Geografia (PPGG) \\ do Instituto de Geociências (IGEO) da Universidade Federal do Rio \\ de Janeiro (UFRJ), Av. Pref. Dulcídio Cardoso 1640 bl. $1 \mathrm{apt}^{\circ}$ \\ 1006, Barra da Tijuca, Rio de Janeiro, RJ, CEP 22620-311, (21) \\ 2484-2784, arq.gcsilva@ig.com.br
}

\begin{abstract}
Resumo
O histórico de ocupação urbana da Barra da Tijuca, no Município do Rio de Janeiro, desde os anos 70, revela que a região se destaca como ícone para grandes investimentos públicos, e sobretudo, privados, alcançando importante desenvolvimento socioeconômico. Entretanto, nota-se que as diretrizes dessa vertiginosa expansão urbana baseiam-se, sobretudo, nos interesses de importantes incorporadores imobiliários que, amparados pelos governos local e regional, visam maximizar seus lucros ainda que em detrimento da manutenção da qualidade do meio ambiente, restringindo as possibilidades de desenvolvimento urbano sustentável.
\end{abstract}

Palavras-chave: sustentabilidade urbana, problemas ambientais, impactos ambientais.

\section{ntrodução}

A temática da qualidade do meio ambiente nas grandes cidades capitalistas perpassa o entendimento da relação entre o processo de expansão urbana, marcado pela ação do capital imobiliário, cujo objetivo é a maximização da rentabilidade por meio da valorização do preço da terra, e a degradação ambiental, que invariavelmente resulta desse processo. Assim, a manutenção da qualidade do meio ambiente depende do equilíbrio na estruturação das cidades no que concerne ao trato com a natureza. A lógica de conservação da natureza nas cidades depende; primeiro, da percepção das formas naturais como elementos atuantes, e não meramente contemplativos, nos processos de desenvolvimento urbano, levando à utilização eficiente dos recursos; segundo, do desenvolvimento de novas políticas econômicas e sociais compatíveis com a evolução tecnológica para reduzir e transformar os resíduos, compreendendo que cada ecossistema tem capacidade limitada de suportar transformações e assimilar resíduos (SPIRN, 1995).

Como exemplo da dinâmica de evolução urbana da maioria das cidades brasileiras, no Rio de Janeiro, a cidade se espraia rumo à zona oeste, na Área de Planejamento 4 (AP-4) ${ }^{1}$, em especial na Região Administrativa da Barra da Tijuca (XXIV RA)2 , onde a Barra da Tijuca é o principal bairro, sendo um dos com maior índice de crescimento da cidade (Figura 1). Segundo dados do Instituto Municipal de Urbanismo Pereira Passos (IPP, 2001e), a população do bairro cresceu quase o seu triplo entre 1980 e 2000. Entretanto, o mesmo desenvolvimento não ocorre quando se verificam os projetos de implantação de infra-estrutura de saneamento ambiental, sobretudo no que concerne ao esgotamento sanitário, corroborando para a degradação ambiental dos corpos d'água da região, devido à poluição hídrica por esgotos domésticos e resíduos industriais. 


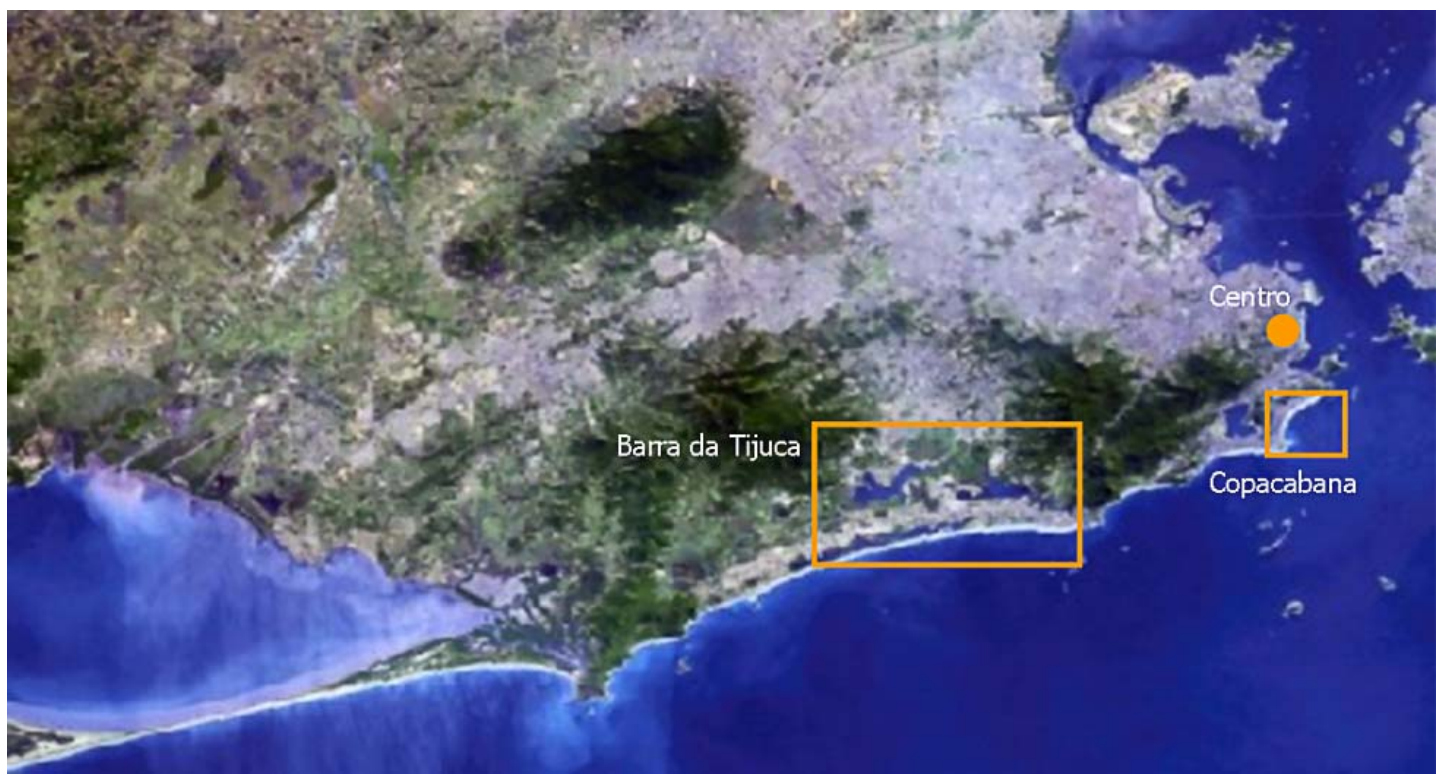

Figura 1: Região da Barra da Tijuca no Município do Rio de Janeiro. Fonte: Modificado de IPP, 2004

bairros: Barra da Tijuca, Recreio dos Bandeirantes, Vargem Grande, Vargem Pequena, Camorim, Joá, Itanhangá, e Grumari. Os bairros de Vargem Grande, Vargem Pequena e Camorim são áreas que ainda conservam alguns traços rurais. Já Prainha e Grumari são áreas preservadas de qualquer ocupação, quase virgens. O bairro da Barra

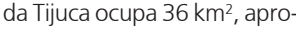
ximadamente a quinta parte da área total da referida região.

3. O Complexo Lagunar da Baixada de Jacarepaguá, formado pelas Lagoas de Tijuca, Camorim, Jacarepaguá, Marapendi e Lagoinha, possui cerca de $300 \mathrm{~km}$ de superfície, abrangendo os bairros pertencentes às Regiões Administrativas de Jacarepaguá (XVI R.A.) e Barra da Tijuca (XXIV R.A.) (ZEE, 2002).
A região da Barra da Tijuca se localiza na Baixada de Jacarepaguá, caracterizada ambientalmente pela presença de lagoas costeiras formadoras do Complexo Lagunar da Baixada de Jacarepaguá ${ }^{3}$, onde se destacam a Lagoa da Tijuca e a Lagoa de Camorim, escolhidas como estudo de caso, principalmente, devido à deterioração da qualidade das águas, ao assoreamento e à eutrofização, decorrente do lançamento de esgoto sem tratamento preliminar. Segundo David Zee (2003), a Baixada de Jacarepaguá possui população residente estimada em 650.000 habitantes com produção diária de 1.881 litros de esgoto por segundo que, invariavelmente, seguem para as lagoas. O despejo de esgoto in natura nesses corpos d'água compromete a qualidade ambiental da região.

Portanto, torna-se essencial uma análise dos impactos e dos problemas ambientais diante da precariedade da qualidade dos recursos hídricos na Região da Barra da Tijuca (XXIV RA), na Baixada de Jacarepaguá, mais especificamente a região localizada no entorno das Lagoas da Tijuca e de Camorim, avaliando os parâmetros que vem norteando o processo de ocupação urbana nas décadas de 70/80/ 90, no que tange ao desenvolvimento sustentável da região.

\section{Cidade Sustentável}

A luta por uma cidade livre de problemas ambientais tem norteado o debate público mundial, especialmente a partir do final da década de 60 e o início da década de 70, quando a deterioração do meio ambiente passou a ser problematizada. No Brasil, contudo, o tema da degradação do meio ambiente adquire maior notabilidade apenas na década de 80. Mundialmente, o marco inicial da preocupação com o meio ambiente é a Conferência de Estocolmo sobre o Meio Ambiente, realizado pela Organização das Nações Unidas (ONU) em 1972, onde se instaurou o conceito de desenvolvimento sustentável. Todavia, o conceito de sustentabilidade é interpretado mais amplamente na Declaração de Cocoyoc, em 1974, sendo publicado enfim no relatório Que Faire da ONU, em 1975. Em 1983, a instituição criou a Comissão Mundial sobre o Meio Ambiente e Desenvolvimento (CMMAD), responsável pela publicação do relatório Nosso Futuro Comum, em 1987. O documento retoma a definição do conceito de desenvolvimento sustentável como aquele que atende "às necessidades do presente sem comprometer a capacidades de as gerações futuras atenderem às suas" (CMMAD, 1991, p. 9). Em 1992, a organização realiza a Eco-92, também co- 
nhecida por Rio-92, na Cidade do Rio de Janeiro. A conferência reuniu 178 países, 114 chefes de Estado, e 1.600 representantes de Organizações NãoGovernamentais (ONGs). A sociedade civil reuniu-se no Fórum Global, paralelamente à conferência, onde foram aprovados diversos documentos, a exemplo da Agenda 21, com propostas de ação para o desenvolvimento sustentável (VIANNA, 1994).

O conjunto desses eventos em defesa do meio ambiente ilustra o pensamento e, por conseguinte, as propostas ecológicas frente à crise ambiental no mundo. Avançando em relação às primeiras propostas ecológicas, Ignacy Sachs instaura o conceito de "ecodesenvolvimento", que abordava a importância da qualidade do desenvolvimento humano como opção política de um modelo de crescimento econômico equilibrado capaz de minimizar a degradação ambiental e maximizar a igualdade social (LAGO, 1984). É fato que o desenvolvimento humano econômico depende dos recursos naturais. Entretanto, o conceito de sustentabilidade implica num limite para a utilização desses recursos, no sentido de minimizar os problemas ambientais, como a redução da biodiversidade e da quantidade de recursos, a poluição, entre outros (HARDOY, 1992).

Segundo Hough (1990), para as cidades se tornarem sustentáveis é preciso que os sistemas de produtos e de energia da vida urbana tragam benefícios ao meio ambiente, a partir de uma visão que contemple a qualidade de vida da população, mas também a qualidade ambiental. Destarte, o conceito de sustentabilidade se aproxima ao de vitalidade, conforme Lynch (1989), que coloca como regra básica que a cidade deve garantir que todo ser humano tenha o direito a suprir suas necessidades vitais básicas. Contudo, a garantia dessa vitalidade depende de uma forma urbana capaz de congregar os diversos sistemas formadores do ecossistema urbano. A cidade é um ecossistema à medida que abriga um conjunto de organismos que interagem com outros de mesma espécie ou de espécies diferentes, num mesmo habitat (LYNCH, 1995). A cidade pode ser encarada como um ecossistema urbano composto de três sistemas: urbano, natural e social (SPIRN, 1995). Ou ainda, como "um imenso e intrigante sistema de sistemas" onde diversos processos devem interagir em equilíbrio dinâmico, sendo: urbano, natural, social, econô- mico e tecnológico (MEINIG, 1979, p. 37). A esse respeito, o conceito de sustentabilidade defendido por Sachs (1993), no que concerne ao desenvolvimento urbano, pressupõe a consideração de cinco dimensões intrínsecas: a sustentabilidade social, econômica, ecológica, espacial, e cultural. Portanto, as dimensões de sustentabilidade se referem aos sistemas da cidade: urbano, natural e social (SACHS, 1993).

O sistema urbano refere-se aos elementos construtivos da cidade: ao sistema viário, ao saneamento ambiental, aos equipamentos públicos, às edificações, aos transportes, etc. Já o sistema natural aborda os elementos naturais que, freqüentemente, são analisados apenas segundo seus valores estéticos sem relação com os demais sistemas formadores da cidade. Segundo Spirn (1995), a percepção das formas naturais como elementos isolados ou desconectados dos demais processos, é responsável pela utilização ineficiente de recursos na cidade. Quanto ao sistema social, trata das relações interpessoais na comunidade urbana que, invariavelmente, obedecem aos processos culturais, políticos e principalmente econômicos. Nas grandes cidades capitalistas, é comum que os processos econômicos se sobreponham aos demais. O sistema econômico, portanto, é atualmente o principal no ecossistema urbano, pois baliza as atividades humanas que levam ao desenvolvimento urbano. Já o sistema tecnológico reflete diretamente às práticas econômicas desenvolvidas pelo homem na cidade (MEINIG, 1979). Segundo Rogers (2001), o entendimento da cidade como sistema ecológico, e não apenas urbano, permite o gerenciamento do uso de seus recursos e resíduos, em favor do desenvolvimento sustentável. Portanto, a construção de uma cidade sustentável depende de um planejamento urbano, cuja visão holística relacione as dimensões econômicas, físicas, e sociais ao meio ambiente. Nesse contexto, surge a defesa da criação de 'cidades compactas', cujas atividades se sobrepõem a partir de um planejamento urbano de uso misto, como forma de solucionar a problemática social e ambiental das cidades atuais.

Rogers (2001) propõe a reinvenção do modelo de 'cidade densa', aquela onde há problemas de superpopulação, pobreza e riscos à saúde, de modo a promover um novo modelo de cidade onde haja um planejamento integrado capaz de minimizar e/ 
Figura 2: Regiões Administrativas no Contexto da $\mathrm{Ba}$ cia Hidrográfica da Baixada de Jacarepaguá. Fonte: Modificado de IPP, 2006. ou mitigar esses problemas sócio-ambientais. Assim, o autor acredita na adoção de um modelo de 'cidade compacta' como "uma cidade densa e socialmente diversificada onde as atividades econômicas e sociais se sobreponham e onde as comunidades sejam concentradas em torno de unidades de vizinhança" (Rogers, 2001, p.23). A 'cidade compacta' exige a rejeição do modelo de planejamento urbano baseado na monofuncionalidade e na predominância do automóvel. Esse novo modelo de cidade se estrutura ao redor de centros de atividades sociais e comerciais junto a pontos nodais de transportes públicos, e pontos focais entorno dos quais se estabelecem as comunidades. É uma rede de vizinhanças, com espaços públicos, que abrigam atividades públicas e privadas sobrepostas. Assim, as 'cidades compactas' requalificam a cidade atual como ambiente ideal à permanência de comunidades, onde haveria a redução do desperdício de energia e de recursos, e a melhoria da qualidade do meio ambiente (Rogers, 2001).

Assim, buscando a sustentabilidade do desenvolvimento urbano é preciso que a dinâmica das grandes cidades capitalistas busque o equilíbrio desse ecossistema, conservando recursos e minimizando resíduos. Entretanto, as políticas públicas de gestão das cidades, freqüentemente, atuam numa intervenção pontual que não pressupõe a conexão entre os diversos sistemas da cidade. Então, ora investe-se em sistemas viários ou em infra-estrutura de saneamento, ora em projetos de embelezamento paisagístico, contudo, sem potencializar a interface existente entre esses. Deve-se, portanto, compreender os processos dos sistemas social e urbano associados aos processos do sistema natural, daí a complexidade do ecossistema urbano. Entretanto, Meinig (1979) ressalta as atividades econômicas, comumente, se sobrepõem às demais. Isso porque, o desenvolvimento econômico tornou-se uma referência obrigatória na ação pública. Se ao contrário, houvesse o reconhecimento de que a cidade é parte da natureza e vice-versa, é provável que as novas políticas públicas permitissem o surgimento de uma cidade livre da degradação ambiental, sustentável enfim.

\section{Barra da Tijuca: Evolução Urbana}

Na Cidade do Rio de Janeiro, a partir do fim dos anos 60, o crescimento urbano vem sendo direcionado para a zona oeste, sobretudo, para a Baixada de Jacarepaguá, onde se insere a região da Barra da Tijuca (XXIV RA, Figura 2).

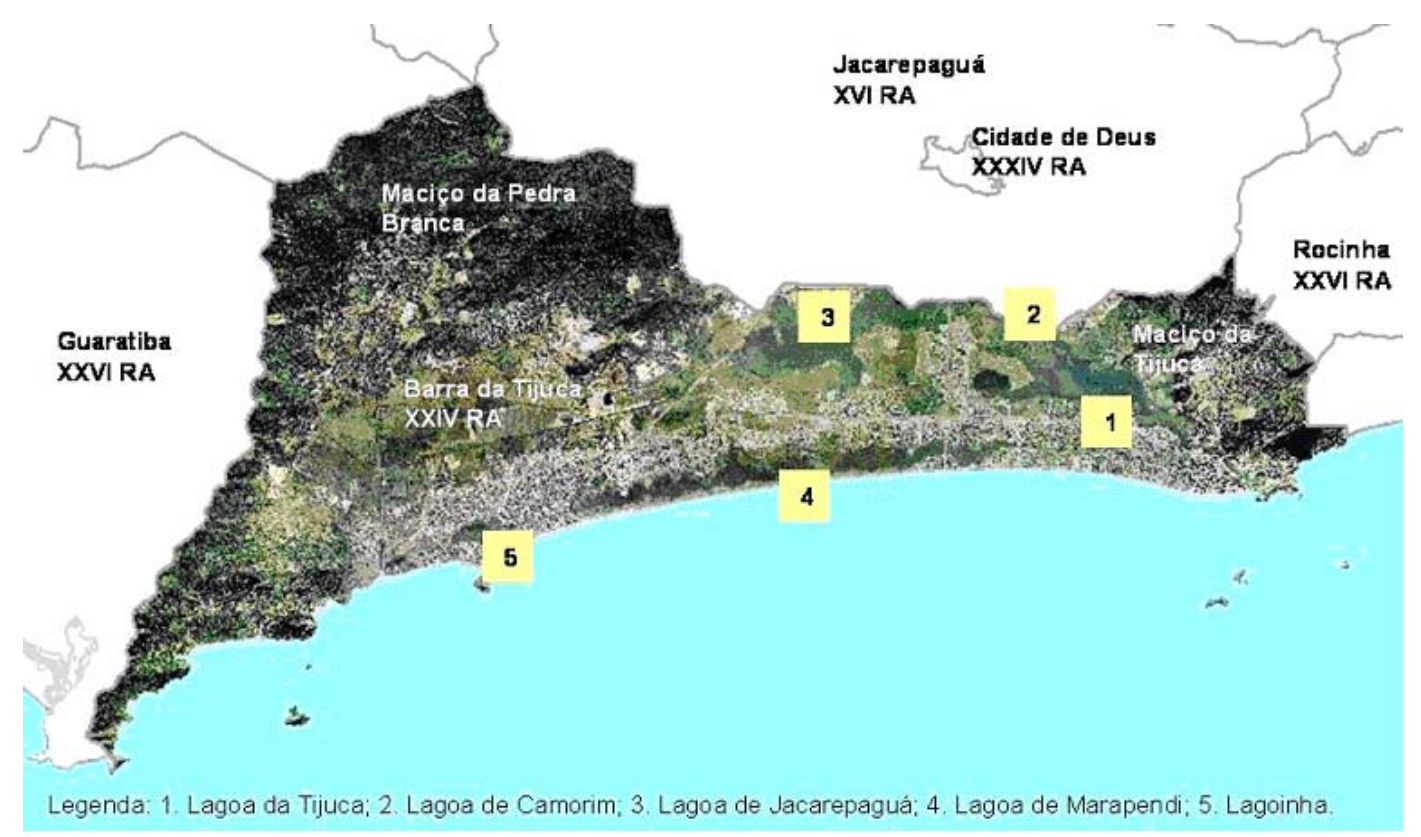




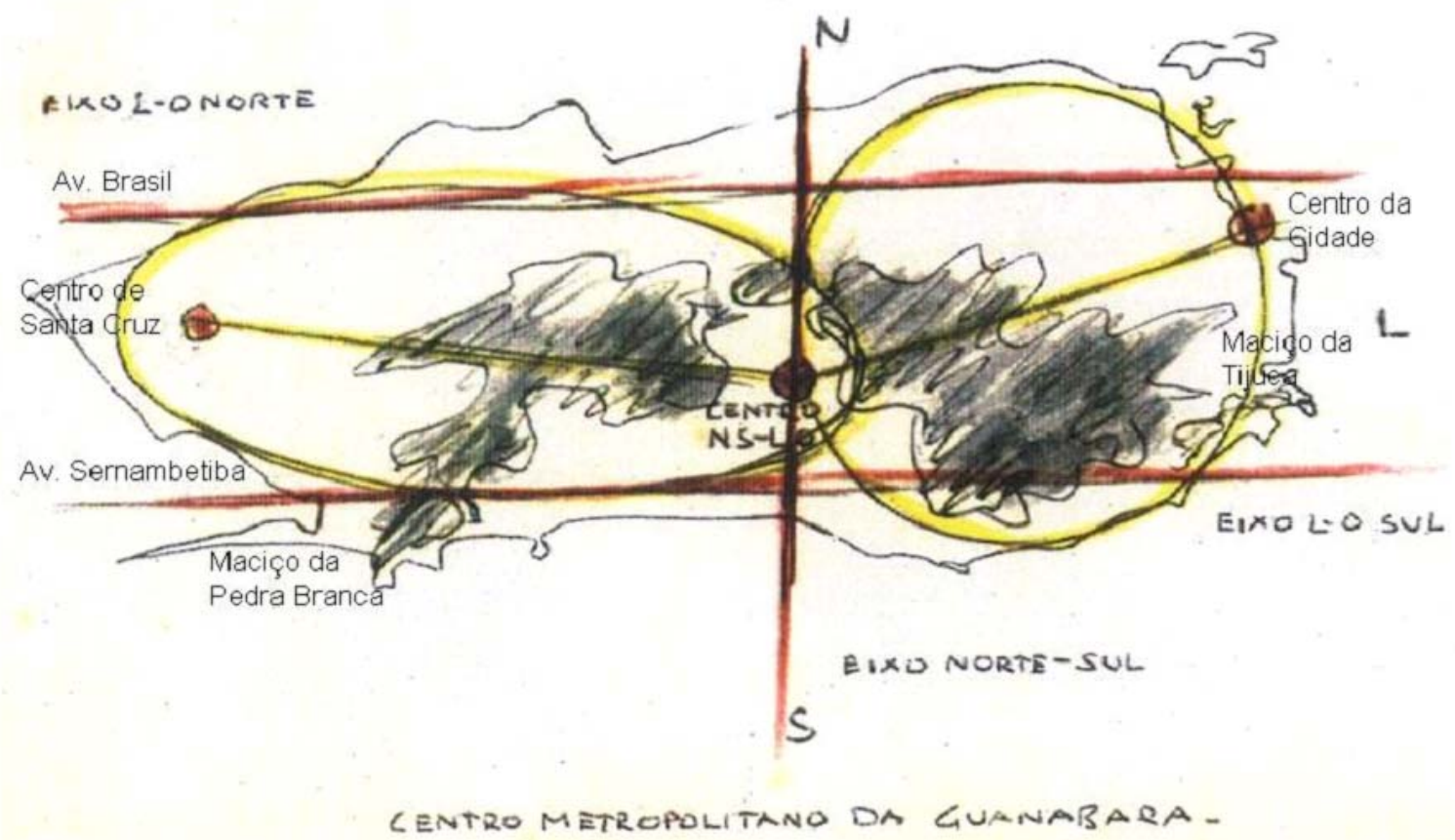

Figura 3: Croquis de Lucio Costa para os Eixos do Plano Piloto da Baixada de Jacarepaguá. Fonte: Modificado de COSTA, 1969.

4. O novo centro de Santa Cruz constava no Plano Doxiadis, de 1963.
O processo tardio de ocupação urbana na Barra da Tijuca, devido ao fato de os Maciços da Tijuca e da Pedra Branca dificultarem o acesso à região, transformou sua paisagem, que era habitacional rural, graças à valorização do preço da terra urbana, segundo a promoção imobiliária destinada às classes de média e alta rendas, bem como o crescimento das favelas, onde reside a população de baixa renda. Outrossim, essa vertiginosa expansão da malha urbana deveu-se, sobremaneira, aos investimentos em infra-estrutura balizados pelo Plano Piloto do arquiteto e urbanista Lucio Costa, de 1969, cuja proposta era elaborar o ordenamento do uso do solo, segundo uma visão global que articulava o novo centro de negócios da Barra da Tijuca, ao centro histórico da Cidade do Rio de Janeiro e ao novo centro de Santa $\mathrm{Cruz}^{4}$, ligando a cidade de leste a oeste. Desse modo, a região surgia como futuro core da cidade, reestruturando o espaço da cidade e, nomeadamente, direcionando a migração populacional rumo à zona oeste (CARDOSO, 1989; Figura 3).

De fato, houve diversos fatores que possibilitaram o admirável processo de ocupação da Barra da Tijuca. Primeiro, o fato de a região abrigar um dos mais belos complexos naturais do Rio de Janeiro, com praias, montanhas, e lagoas, foi eficientemente explorado pelas grandes empresas imobiliárias. Segundo, devido à concentração da propriedade das terras por quatro grandes proprietários, acelerando o processo de ocupação. Terceiro, nas décadas de 70 e 80, os investimentos do Governo Federal, por meio dos recursos do Sistema Financeiro de Habitação (SFH), beneficiou o processo de produção das grandes incorporadoras imobiliárias na região, visando às camadas sociais médioaltas. Por último, os massivos investimentos públicos em obras de infra-estrutura viária, de acordo com o Plano Piloto de Lucio Costa, especialmente 
5. Em 1980, havia 23.485 habitantes no bairro da Barra da Tijuca contra 5.642 no Recreio dos Bandeirantes. Em 1960, esse número cresceu para 82.702 e 20.414 habitantes, respectivamente (ANUÁRIO, 1997).
6. A inserção de Copacabana se deve ao fato de possuir a segunda maior densidade populacional no Município do Rio de Janeiro. de 1966 a 1982, facilitaram o acesso ao bairro, corroborando para a atividade imobiliária (LEITÃO, 1995).

Assim, esse conjunto de investimentos na Barra da Tijuca, sejam públicos sejam privados, para atender às necessidades da industria imobiliária, permite-nos compreender a vertiginosa expansão demográfica nos últimos trinta anos, como o bairro com o maior índice de crescimento populacional da Cidade do Rio de Janeiro. No período entre 1960 e 2000 (Tabela 1, Figuras 4 e 5), a população da Barra da Tijuca (XXIV RA) cresceu 38,35 vezes mais que a do Município e 21,91 vezes mais que a de Jacarepaguá (XVI RA). Essa expansão urbana da região incrementou a densidade populacional, principalmente, nos últimos vinte anos, quando a taxa de crescimento da densidade da população na região representou 3,69 vezes a do Município; sobretudo, em decorrência do crescimento de áreas residenciais graças à implantação de grandes condomínios fechados com edifícios de apartamentos: $85 \%$ dos imóveis são residenciais, dos quais 68,5\% são apartamentos (IPP, 2001c; Tabela 2)5. Segundo Ribeiro (1997), a Barra da Tijuca repete a lógica da incorporação imobiliária instaurada em Copacabana, quanto à intenção de aumentar a densidade local. É importante, outrossim, observar que essa densificação urbana decorre do crescimento de áreas residenciais graças à implantação de grandes condomínios fechados com edifícios de apartamentos: $85 \%$ dos imóveis são residenciais, dos quais $68,5 \%$ são apartamentos (IPP, 2001C).

Tabela 1. População Residente no Município do Rio de Janeiro, Segundo Regiões Administrativas

\begin{tabular}{lrrrrrrr}
\hline Local & \multicolumn{1}{c}{1960} & 1970 & 1980 & 1991 & 1996 & 2000 & $\begin{array}{c}\text { Taxa de } \\
\text { Crescimento }\end{array}$ \\
\hline Rio de Janeiro & 3.307 .163 & 4.251 .618 & 5.090 .700 & 5.480 .778 & 5.551 .538 & 5.857 .904 & 1,77 \\
Jacarepaguá & 164.092 & 235.238 & 315.623 & 428.073 & 446.360 & 469.682 & 2,86 \\
Barra da Tijuca & 2.580 & 5.779 & 40.726 & 98.229 & 129.632 & 174.353 & 67,57
\end{tabular}

Fonte: Modificado de IPP, 2001e.

Tabela 2. Densidade Populacional na Barra da Tijuca (hab/ha), em $2000^{6}$

$\begin{array}{lcccc}\text { Local } & 1980 & 1991 & 2000 & \text { Taxa de Crescimento } \\ \text { Rio de Janeiro } & 50,9 & 54,8 & 58,6 & 1,15 \\ \text { Copacabana } & 442,5 & 351,2 & 333,6 & 0,75 \\ \text { Jacarepaguá } & 33,1 & 45,0 & 49,3 & 1,49 \\ \text { Barra da Tijuca } & 3,2 & 7,7 & 13,6 & 4,25\end{array}$

Fonte: Modificado de IPP, 2001b. 

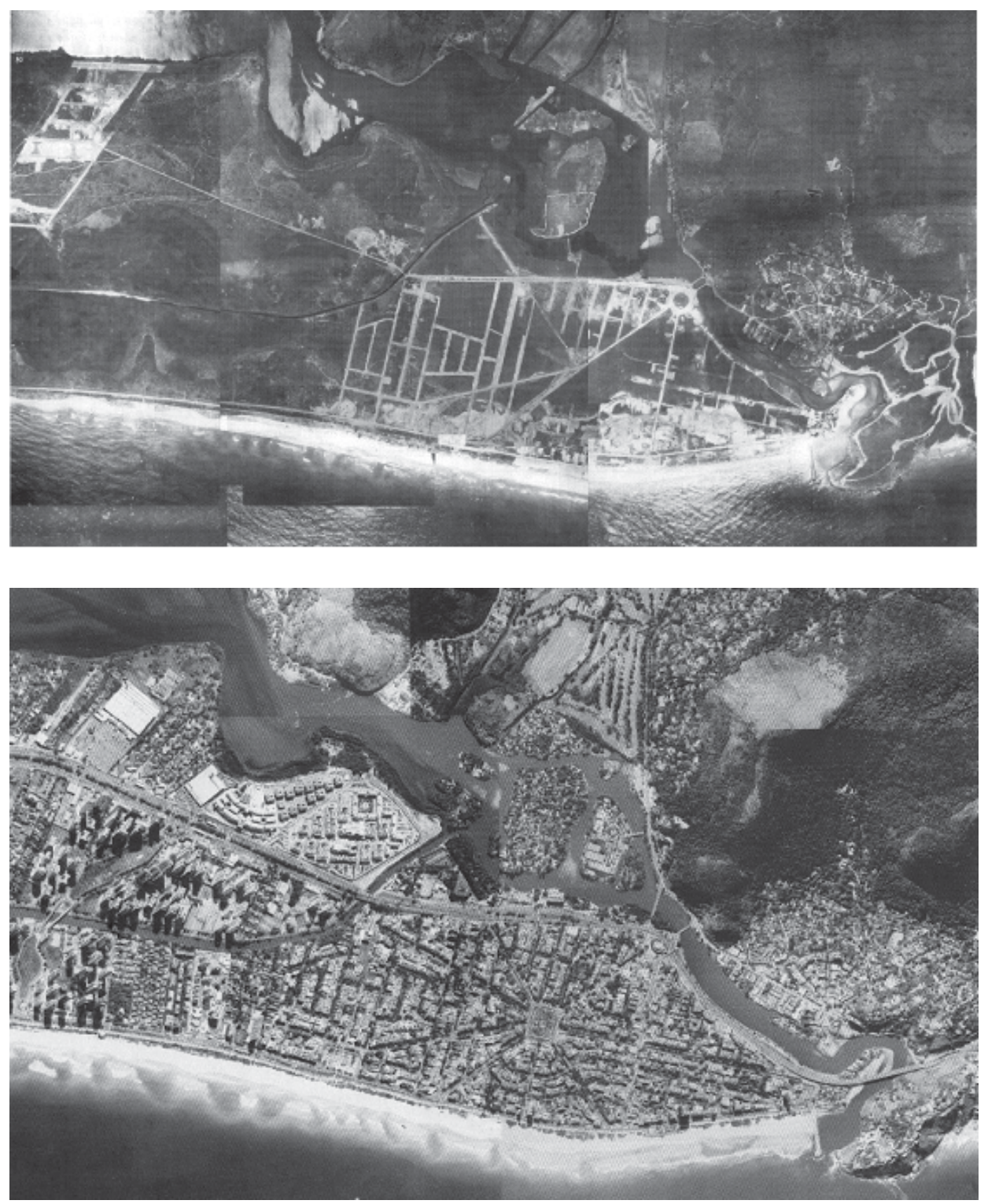

Figura 4: Trecho da Barra da Tijuca e Lagoa da Tijuca, em 1955. Fonte: SMAC - Secretaria Municipal de Meio Ambiente, 2000

Figura 5: Trecho da Barra da Tijuca e Lagoa da Tijuca, em 1999. Fonte: SMAC, Secretaria Municipal de Meio Ambiente, 2000.
Na Barra da Tijuca, igualmente a demais regiões da Cidade do Rio de Janeiro, a malha formal cresce enquanto surgem as áreas residenciais informais (Tabela 3, Figuras 6 e 7). Entre 1991 e 2000, as áreas regulares cresceram anualmente 1,7\% em Jacarepaguá e 6\% na Barra da Tijuca, enquanto o crescimento anual das favelas foi de $7,5 \% \mathrm{em}$
Jacarepaguá e 10\% na Barra da Tijuca (IBGE, 2006). Portanto, nesse período, para cada 100 novos moradores da cidade formal surgiram 86 moradores em favela. Entre 1991 e 2000, o crescimento da população residente em favelas na Barra da Tijuca (XXIV RA) foi o maior na Área de Planejamento 4 (AP-4) (IPP, 2001b). 
Tabela 3. Evolução das favelas na Região da Barra da Tijuca

\begin{tabular}{lccc}
\hline Local & 1996 & 2000 & Taxa de Crescimento \\
\hline Rio de Janeiro & 952.429 & 1.092 .783 & 1,14 \\
Área de Planejamento 4 (AP -4) & 86.157 & 144.298 & 1,67 \\
Jacarepaguá (XVI RA) & 70.605 & 113.227 & 1,60 \\
Barra da Tijuca (XXIV RA) & 15.552 & 31.071 & 1,99 \\
\hline
\end{tabular}

Fonte: Modificado de IPP, 2001e.
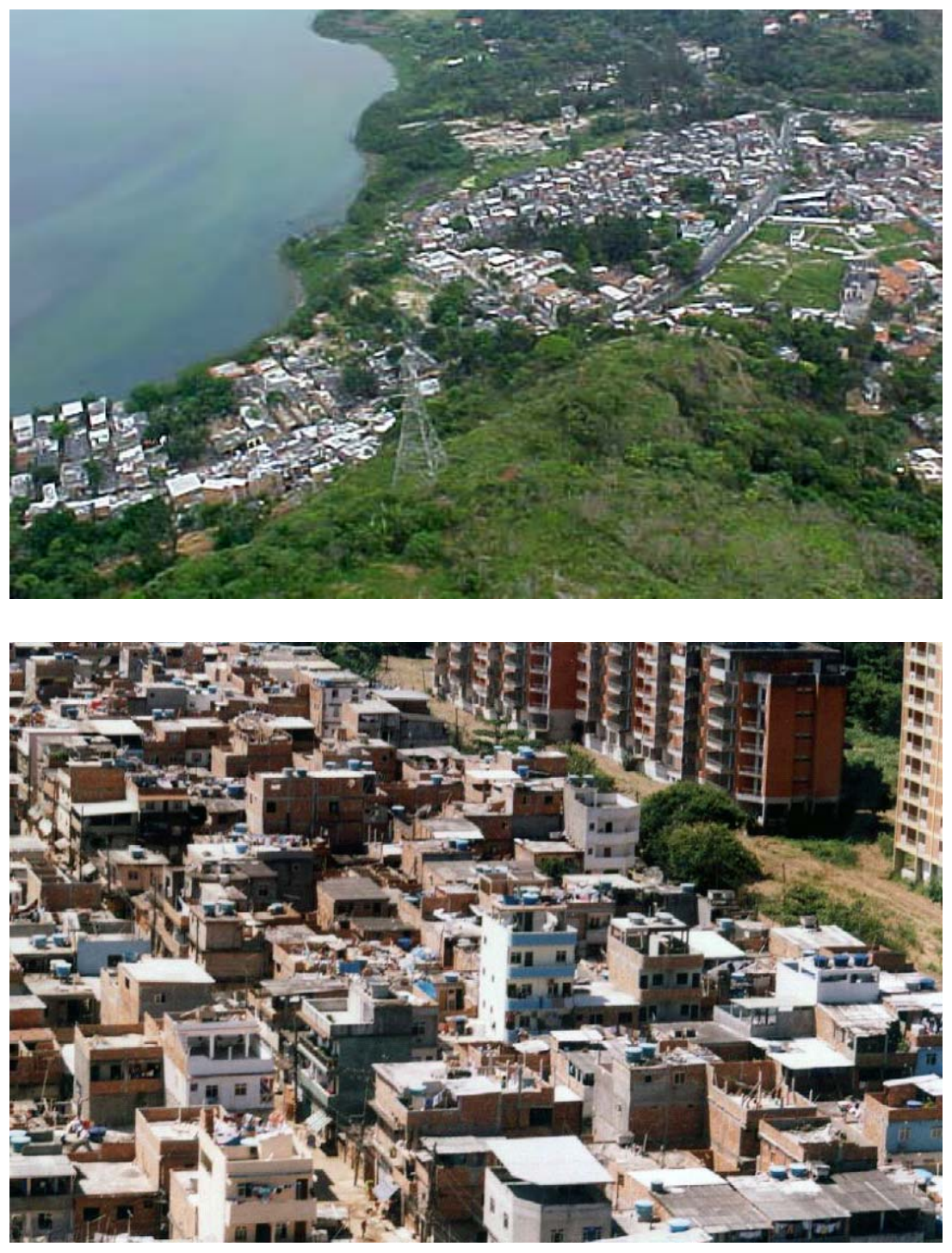
7. O Índice de Desenvolvimento Humano Municipal (IDH-M) é obtido pela média aritmética simples de três índices referentes às dimensões Longevidade (IDHM-Longevidade), Educação (IDHM-Educação) e Renda (IDHM-Renda) (IPP, 2001c).
Portanto, os investimentos em grandes empreendimentos imobiliários na região, especialmente os residenciais dirigidos para as classes sociais mais abastadas permitiram o progressivo desenvolvimento socioeconômico da região. Conforme o Índice de Desenvolvimento Humano (IDH) do Município do Rio de Janeiro, a Barra da Tijuca se classifica como região de médio-alto desenvolvimento humano, ocupando o quinto lugar no ranking da cidade
(IPP, 2003; Tabela 4) ${ }^{7}$. Note-se que o Índice de Renda (IDH-R) é o indicador balizador para o surgimento de empreendimentos imobiliários residenciais de luxo. Por exemplo, em 2003, a renda média da Região da Barra da Tijuca (XXIV RA), de 13 salários mínimos, era maior do que o dobro da renda média do Município, de cerca de seis salários mínimos (IPP, 2003)

Tabela 4. Índice de Desenvolvimento Humano Municipal (IDH), por ordem de IDH, segundo Regiões Administrativas, de 1991 a 2000

\begin{tabular}{|c|c|c|c|c|c|c|c|c|}
\hline \multirow[t]{2}{*}{$\begin{array}{l}\text { Região } \\
\text { Administrativa }\end{array}$} & \multicolumn{2}{|c|}{$\begin{array}{l}\text { Índice de } \\
\text { Longevidade } \\
\text { (IDH - L) }\end{array}$} & \multicolumn{2}{|c|}{$\begin{array}{l}\text { Índice de Educação } \\
\text { (IDH -E) }\end{array}$} & \multicolumn{2}{|c|}{$\begin{array}{l}\text { Índice de Renda } \\
\quad(\text { ID H-R) }\end{array}$} & \multicolumn{2}{|c|}{$\begin{array}{c}\text { Índice de } \\
\text { Desenvolvimento } \\
\text { Humano Municipal (IDH) }\end{array}$} \\
\hline & 1991 & 2000 & 1991 & 2000 & 1991 & 2000 & 1991 & 2000 \\
\hline Copacabana & 0,780 & 0,879 & 0,953 & 0,990 & 0,964 & 1,000 & 0,899 & 0,956 \\
\hline Lagoa & 0,784 & 0,864 & 0,947 & 0,989 & 1,000 & 1,000 & 0,910 & 0,951 \\
\hline Botafogo & 0,788 & 0,859 & 0,970 & 0,990 & 0,948 & 0,993 & 0,902 & 0,947 \\
\hline Tijuca & 0,751 & 0,829 & 0,962 & 0,987 & 0,894 & 0,954 & 0,869 & 0,923 \\
\hline Barra da Tijuca & 0,741 & 0,795 & 0,891 & 0,961 & 0,978 & 1,000 & 0,870 & 0,918 \\
\hline Jacarepaguá & 0,731 & 0,780 & 0,892 & 0,933 & 0,770 & 0,819 & 0,798 & 0,844 \\
\hline
\end{tabular}

Fonte: Modificado de IPP, 2001e.

A esse despeito, uma pesquisa da Associação de Dirigentes de Empresas do Mercado Imobiliário (ADEMI-RJ, 2004), para o segundo semestre de 2003, verificou que em relação às unidades escrituradas, no ranking de vendas de unidades vendidas: Jacarepaguá ocupou o primeiro lugar com 569; Barra da Tijuca, o segundo com 347; e Recreio dos Bandeirantes, o terceiro com 131. Entretanto, na média do segundo semestre de 2003, o bairro que disponibilizou o maior número de unidades para a venda foi a Barra da Tijuca (1.079), seguida por Jacarepaguá (971) e depois pelo Recreio dos Bandeirantes (638). Recentemente, o destaque da região da Barra da Tijuca no setor imobiliário residencial se deveu, sobretudo, à implantação de sete dos 17 locais de provas dos Jogos Panamericanos de 2007 (RIO 2007) (VILA, 2006b). Isso graças ao enorme sucesso do empreendimento imobiliário Vila Pan-Americana, em construção na Barra da Tijuca pela Agenco, com fi- nanciamento da Caixa Econômica, que teve seus 1350 apartamentos, sendo $91 \%$ do total, vendidos em dez horas. Ou seja, quase dois imóveis negociados por minuto. Esse evento corroborou, inclusive, para que a W/Brasil, agência de propaganda que assina a campanha de lançamento da Vila, e a Patrimóvel, imobiliária responsável pela venda de 75\% das unidades, inscrevessem a Vila Pan-Americana no Guiness Book, em categorias diferentes e separadamente (VILA, 2006a).

Enfim, a rápida ocupação urbana da Barra da Tijuca, impulsionada sobremaneira pela especulação imobiliária voltada para classes sociais mais ricas, provocou tanto o surgimento de aterros indiscriminados, como a ocupação regular e irregular das margens de rios e lagoas. Igualmente, devido à falta de infra-estruturas de saneamento para a coleta e o tratamento dos esgotos, agravou-se a po- 
luição dos corpos hídricos do Complexo Lagunar da Baixada de Jacarepaguá, notadamente, das Lagoas da Tijuca e de Camorim, por problemas de assoreamento, de destruição da vegetação de manguezais, etc. (HOUGH, 2000; RODRIGUES, 2000). Desse modo, cabe, primeiramente, investigar os possíveis impactos ambientais decorrentes do processo de desenvolvimento urbano da região, verificando o atendimento à temática de sustentabilidade ambiental. Em segundo, analisar os problemas ambientais encontrados na região, em especial, os suscitados pela poluição hídrica das Lagoas da Tijuca e de Camorim, as mais comprometidas quanto à qualidade ambiental.

\section{Impactos Ambientais na Barra da Tijuca}

Os impactos ambientais encontrados na área de estudo refletem a forma predatória de expansão urbana que vem sendo implantada na Região da Barra da Tijuca. Para a avaliação de impactos ambientais (AIA) poder-se-ia empregar, apenas, as categorias estabelecidas pela Resolução CONAMA $N^{\circ} 001 / 86$ que, contudo, se mostram incompletas quanto ao entendimento das relações de causa e efeito entre os aspectos físicos, biológicos, químicos, sociais, políticos e culturais do ambiente urbano (CONAMA, 1986). Por isso, para a presente análise, optou-se pela conjunção entre a Metodologia de Listagem, ou seja, Check-List, as categorias de impactos estabelecidos pela Resolução CONAMA No 001/86, e a metodologia proposta por Coelho (2001), que busca o entendimento da interação entre os processos biofísicos, políticos-econômicos e socioculturais, que configuram o conceito de impacto ambiental.

Segundo a autora, os impactos ambientais urbanos devem ser analisados como mudanças de relações ecológicas e sociais, que se referem a um estágio de um processo de transformação contínuo, numa perspectiva de metamorfose entre o fato natural e o fato político e social. Se as relações entre natureza e sociedade pressupõem mutabilidade constante, isso significa que, provavelmente, "o impacto ambiental é, ao mesmo tempo, produto e produtor de novos impactos", pois tanto sofre a ação das atividades humanas quanto se transforma, instaurando assim uma nova relação entre o natural e o social, onde "o ambiente é passivo e ativo" (COELHO, 2001, p. 23). Conforme a autora, no entanto, no estudo dos impactos ambientais há que se analisar o tema sob dois aspectos. Primeiro, as questões ambientais são resultado da associação de forças políticas e sociais, que freqüentemente priorizam os interesses das classes dominantes. Segundo, a classificação usual de positivos e negativos deve ser relativizada em função do grupo social referente, pois o que é positivo para um grupo social pode ser negativo para outro, e vice-versa.

A análise dos diversos fatores que influem no espaço urbano da Baixada de Jacarepaguá, mais especificamente no entorno das Lagoas da Tijuca e de Camorim, quanto à qualidade das águas, pode ser observada segundo a Tabela 5. Note-se que os impactos ambientais encontrados na área de estudo se correlacionam, direta ou indiretamente, com a explosão demográfica da região da Barra da Tijuca a partir da década de 70, mais especialmente nos anos 80 , quando então havia melhorado a acessibilidade à região, através da implantação de vias expressas e da pavimentação de vias locais. Esses fatores são responsáveis por alguns impactos ambientais tais qual a alteração da paisagem, a modificação do uso do solo, o incremento econômico de atividades comerciais e de serviço, entre outros. Outrossim, associam-se à falta de infraestrutura de saneamento ambiental, notadamente, quanto à coleta, ao tratamento e ao destino final dos efluentes domésticos, tornando inevitável o surgimento de problemas ambientais como: diminuição do espelho d'água das lagoas, poluição e eutrofização dos corpos hídricos, assoreamento das lagoas. Igualmente, esses impactos combinados à predatória especulação imobiliária, que freqüente-mente utiliza aterros ilegais e indiscrimi-nados, promovem a destruição de vegetação de manguezal e a redução das faixas marginais das lagoas.

Conforme a Resolução CONAMA № 001/86 e a Deliberação CECA No 1078/87 (RJ), as categorias de impactos estabelecidos, são: positivos e negativos, diretos e indiretos, imediatos e a médio e a longo prazos, temporários e permanentes. No que concerne à análise dos impactos ambientais existentes nas Lagoas da Tijuca e de Camorim, de acordo com as categorias supracitadas, surgem alguns aspectos (Tabela 6). 
Tabela 5. Check-list dos impactos ambientais urbanos encontrados

Fatores Correspondentes ao Impacto Biogeofísico Fatores Correspondentes ao Impacto Sócio-Econômico

\section{Fatores Físicos}

Temperatura

Turbidez

Sólidos

Cor

Odor

\section{Fatores Químicos}

Oxigênio Dissolvido (OD)

Demanda Química de Oxigênio (DQO)

$\mathrm{pH}$

Nitrogênio

Fósforo

Metais pesados

\section{Fatores Biológicos}

Demanda Bioquímica de Oxigênio (DBO)

Coliformes

Fauna

Flora

\section{Território}

Uso ina dequado dos recursos naturais

Alteração do uso do solo urbano

Densificação demográfica

\section{Paisagem}

Alteração da paisagem urbana

Alteração de sistemas naturais

\section{Fatores Sócio-Econômicos}

Alteração da qualidade de vida

Incremento econômico de atividades comerciais industriais e de serviços

Construção de moradias

Implantação de infra -estrutura de transportes

Implantação de infra -estrutura sanitária

Implantação de serviços públicos

Implantação de equipamentos urbanos

Fonte: Modificado de Magrini (1990); Mota (1999).

Tabela 6. Classificação dos impactos ambientais urbanos encontrados

$\begin{array}{ll}\text { Impactos } & \text { Conceito } \\ \text { Negativo ou Adverso } & \text { A ação antrópica prejudica a qualidade de fator ou parâmetro ambiental } \\ \text { Direto } & \text { O impacto resulta de uma simples relação de causa e efeito } \\ \text { Médio e Longo Prazo } & \text { O impacto se manifesta por certo tempo após a ação } \\ \text { Permanente } & \text { Seus efeitos não cessam imediatamente após o término da ação antrópica } \\ \text { Local } & \text { A ação afeta apenas o próprio sítio e suas imediações }\end{array}$

Fonte: Modificado de Deliberação CECA No 1078/87 (RJ).

Portanto, visando à avaliação dos impactos ambientais na área de estudo, de acordo com a metodologia proposta por Coelho (2001), faz-se necessário compreender os diversos aspectos multidimensionais na origem dessa problemática. Primeiro, a transformação do espaço urbano da Barra da Tijuca deve-se ao interesse dos proprietá- rios de terras em converter a terra rural em urbana a fim de agregar valor a essa. Assim, os proprietários fundiários, interessados no seu valor de troca, pressionam o Estado, em especial o Poder Público Municipal, com o objetivo que se beneficiar do processo de regulação do uso do solo e do zoneamento urbano (CORRÊA, 2002). Entretanto, 
o incremento do valor da terra urbana depende de alguns fatores, dos quais se destacam dois na área de estudo: a infra-estrutura urbana e o atrativo físico do local. No caso da Barra da Tijuca, se anteriormente suas terras rurais se mostravam como periferia urbana, é graças à redução de terrenos solváveis na nobre zona sul da cidade que tanto os proprietários de terras quanto os promotores imobiliários exploram sua paisagem por meio de marketing imobiliário estrategicamente voltado para as classes mais abastadas, e transformam a antiga periferia urbana em região de bairros seletivos. Igualmente, a partir da década de 60, o Estado promoveu inúmeras intervenções urbanas essenciais ao sucesso dos empreendimentos imobiliários locais: implantação e calçamento de vias, iluminação pública, coleta de lixo, abastecimento de água e provisão de energia elétrica e gás, ainda que em detrimento da implantação de sistema de esgoto sanitário, solução adiada pelo Poder Público devido ao seu elevado custo (EVANGELISTA, 1989).

Cabe ressaltar que, apenas em 2001, o Governo do Estado inicia o Programa de Despoluição e Saneamento Básico da Baixada de Jacarepaguá, visando à construção de uma estação de tratamento de esgoto, que seria ligada ao emissário submarino, bem como à implantação de 286 quilômetros de redes de esgoto em 60 mil residências e mais 11 elevatórias (GOVERNO, 2000). Contudo, o programa teve as obras interrompidas e adiadas várias vezes, ora por falta de condições climáticas favoráveis ora por causa de dívidas com construtoras, sendo que o principal problema assenta-se na proposta de não tratar a região como um todo, visto que o programa atende apenas à população do bairro da Barra da Tijuca e de parte de Jacarepaguá. Assim, quanto à implantação de sistema de saneamento ambiental, as empresas imobiliárias optaram ora pelas fossas sépticas ora pelas estações de tratamento de esgoto (ETE) compactas. Entretanto, a manutenção das referidas ETE ser custeada pelos condomínios, provocando ora precariedade ora inexistência desse serviço, contribuindo, assim, para o aumento da degradação dos corpos d'água da região (SANTIAGO, 2004).

Portanto, nas últimas décadas, a falta de equipamento sanitário adequado não tem limitado a ação do capital imobiliário na região, corroborando para o surgimento dos problemas ambientais, tais qual a diminuição do espelho d'água das lagoas, a poluição e a eutrofização dos corpos hídricos, e o assoreamento das lagoas.

\section{Problemas Ambientais nas Lagoas da Tijuca e de Camorim}

Contemporaneamente, a maioria das cidades privilegia as metas econômicas em detrimento dos valores sociais, prejudicando o meio ambiente, pois que raramente é compreendido como um sistema atuante e vital no processo de urbanização. À medida que a cidade se torna mais complexa, graças ao desenvolvimento das atividades humanas, tendem a se acentuar os impactos sobre o meio ambiente. Esses impactos ambientais revelam o processo de degradação ambiental, que se refere "à destruição e à ruptura do equilíbrio de ecossistemas naturais", sendo entendida como a ruína da qualidade de vida de uma coletividade na esteira dos impactos negativos sobre o ambiente - tanto o "ambiente natural" quanto o "ambiente construído" - por fenômenos ligados à dinâmica e à "lógica" do modelo civilizatório e do modo de produção capitalistas (SOUZA, 2000, p. 113).

A respeito da relação entre o modelo socioeconômico e seus impactos no meio ambiente, Foladori (2001, p. 102) escreve: "(...) os problemas ambientais da sociedade humana surgem como resultado da sua organização econômica e social e que qualquer problema aparentemente externo se apresenta, primeiro, como um conflito no interior da sociedade". A reflexão do autor abrange, em princípio, todos os elementos que configuram a problemática ambiental nas sociedades contemporâneas. Primeiro, define que, os problemas ambientais são produto dos sistemas econômico e social de uma determinada sociedade. Nesse contexto, retomando a compreensão da cidade como ecossistema urbano, onde se enlaçam diversos sistemas, percebe-se que o autor vem ao encontro de outros que, crêem serem os principais sistemas que engendram a cidade, de fato, os sistemas econômico e social. Ainda, o entendimento do autor quanto à origem primeira dos problemas ambientais aborda o tema dos conflitos sociais que surgem em torno, principalmente, das atividades econômicas. Ou seja, apenas as atividades econômicas de produção não res- 
8. O primeiro informe do Clube de Roma, sob o título Os limites do crescimento, preconizava a diminuição das taxas de crescimento demográfico como solução aos problemas ambientais nas grandes cidades mundiais.

9. Sobre FMP, ver Artigo $2^{\circ}$ da Lei no 4771 , de 15 de setembro de 1965, Estado do Rio de Janeiro (SERLA). pondem pelo surgimento de problemas ambientais, visto que esses dependem de outros sistemas para se insurgirem, como o sistema social.

Segundo Foladori (2001), os problemas ambientais podem ser reduzidos a: depredação de recursos, poluição por detritos, superpopulação e pobreza. O primeiro refere-se à extração de recursos, dos minérios à água, a ritmos mais elevados que a capacidade de reprodução natural do ecossistema. O segundo trata da incapacidade do ecossistema em reciclar naturalmente os resíduos, como os resíduos radioativos, os poluentes de corpos hídricos, etc. Portanto, os resíduos somente geram poluição quando lançados ao meio ambiente em velocidade maior que a de sua absorção natural. O último aborda a superpopulação como a população urbana marginal ao processo produtivo, ou seja, aqueles incapazes de se incorporarem ao ciclo do capital, acarretando por fim a pobreza. Note-se que o problema da superpopulação não pode ser analisado isoladamente, ou retoma-se a proposta equivocada de crescimento zero instaurada pelo Clube de Roma em $1972^{8}$. É preciso compreendê-lo dentro da visão sistêmica que configura as sociedades e, conseqüentemente, as cidades. Ora, se há superpopulação significa que, provavelmente, a política econômica mostra-se incapaz de promover justiça social, gerando tanto a pobreza quanto outros problemas sociais. O problema da superpopulação nas cidades tornou-se bastante evidente na América Latina, a partir dos anos 70, com a migração intensa do campo para a cidade, decorrente da mecanização agrícola. Caso fosse possibilitada a implantação de uma política econômica e social capaz de promover o desenvolvimento para essa população migrante, dificilmente haveria o excedente de população urbana. Conforme Foladori (2001), é importante contextualizar a interação do trabalhador com ambos os meios de produção e o meio ambiente, e a maneira como se relacionam os trabalhadores dentro do processo produtivo. Incluem-se, aí, as relações de propriedade e/ou de apropriação dos meios de produção e da natureza. A crítica do autor referese ao fato de que a crise ambiental não é discutida segundo a compreensão da forma social de produção, a partir dos momentos históricos e das interconexões de classes sociais, e sim, conforme seus efeitos no meio ambiente.
Os problemas ambientais, enfim, são todos aqueles que afetam negativamente, de forma direta ou indireta, a qualidade de vida dos indivíduos, congregando tanto o ambiente natural quanto o ambiente construído. Nesse sentido, ainda, os impactos negativos da sociedade sobre o meio ambiente voltam-se contra essa por meio de catástrofes e problemas ambientais, restringindo sua interação tanto com o espaço natural quanto com o espaço social, segundo uma dinâmica cíclica de causa e efeito. De fato, o tema dos problemas ambientais emerge, no que concerne ao estudo do histórico da ocupação urbana da Barra da Tijuca, devido à incapacidade do Poder Público em promover sistema de saneamento ambiental para a região capaz de impedir o solapamento da qualidade ambiental dos corpos d'água do sistema lagunar da região.

O Complexo Lagunar da Baixada de Jacarepaguá, formado pelas lagoas de Tijuca, Camorim, Jacarepaguá, Marapendi e Lagoinha, possui cerca de $300 \mathrm{~km}^{2}$ de superfície, abrangendo os bairros pertencentes às Regiões Administrativas de Jacarepaguá (XVI RA) e Barra da Tijuca (XXIV RA), na Área de Planejamento 4 (AP-4) do Município do Rio de Janeiro (Figura 8). O sistema, formado pelas Lagoas de Tijuca, Camorim, Jacarepaguá, com cerca de 9,3 $\mathrm{km}^{2}$ de espelho d'água, vem sofrendo sérios prejuízos devido à contaminação de suas águas em função, principalmente, da falta de equipamento sanitário na região.

No que concerne à degradação ambiental das Lagoas da Tijuca e de Camorim, percebe-se duas principais condições responsáveis. A primeira condição se refere à ocupação irregular que, geralmente acompanhada de aterros indiscriminados, especialmente nas Faixas Marginais de Proteção (FMP) ${ }^{9}$, está à margem do processo de licenciamento pelos órgãos públicos competentes. Essa forma de ocupação ocorre tanto nos condomínios residenciais, por ação das grandes incorporadoras imobiliárias, quanto nas favelas, por ação dos moradores de baixa renda. A segunda condição se deve à falta de equipamento sanitário para recoIher e tratar os esgotos despejados in natura, pelos imóveis comerciais, industriais e residenciais. De acordo com a Tabela 7, observam-se algumas violações de padrões no que concerne à qualidade das águas das Lagoas da Tijuca e de Camorim. 


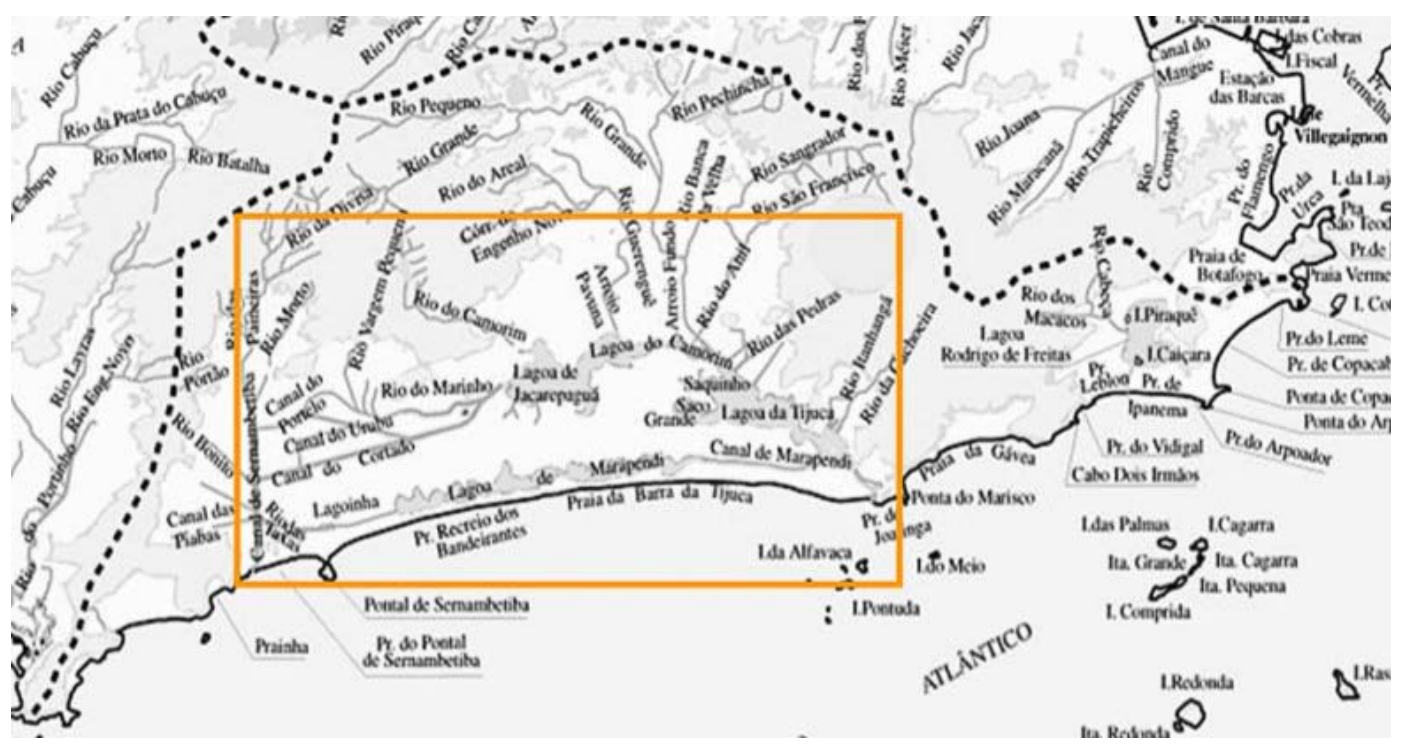

Figura 8: Hidrografia da Região - Bacia das Lagoas Costeiras. Fonte: IPP, 1997.

10. UTN se refere à Unidade de Turbidez Nefelométrica. NMP se refere ao Número Mais Provável.
Tabela 7. Monitoramento da qualidade das águas na área de estudo. ${ }^{10}$

\begin{tabular}{|c|c|c|c|c|c|c|c|}
\hline Lagoas & Período & $\begin{array}{l}\text { Turbidez } \\
\text { (UTN) }\end{array}$ & $\begin{array}{c}\text { Temperatura } \\
\left({ }^{\circ} \mathrm{C}\right)\end{array}$ & $\begin{array}{c}\mathrm{OD} \\
\left(\mathrm{mg} / \mathrm{L} \mathrm{O}_{2}\right)\end{array}$ & $\begin{array}{c}\text { Salinidade } \\
(\%)\end{array}$ & $\begin{array}{l}\text { Coliformes Totais } \\
\text { (NMP/100mL) }\end{array}$ & $\begin{array}{c}\text { E. Coli } \\
\text { (NMP/100mL) }\end{array}$ \\
\hline \multirow[t]{14}{*}{ Tijuca } & *1970 & $\ldots$ & 24,33 & $\ldots$ & $\ldots$ & 410 & $\ldots$ \\
\hline & *1978 & $\ldots$ & 27,7 & 7,8 & 19,13 & 9.900 & $\ldots$ \\
\hline & *1985 & & 22,5 & 2,4 & 9,5 & 49.000 & 13.000 \\
\hline & *1993 & $\ldots$ & 26,03 & $>15,0$ & 8,3 & 115.000 & 60.000 \\
\hline & **1996 & 12,8 & 25,3 & 5,7 & 9,7 & 4.318 .090 & 248.157 \\
\hline & **1997 & 26,6 & 25,8 & 5,4 & 14,9 & 2.513 .673 & 497.886 \\
\hline & **1998 & 24,2 & 24,2 & 5,0 & 8,5 & 17.890 .166 & 381.222 \\
\hline & **1999 & 19,7 & 25,5 & 5,0 & 10,2 & 4.135 .333 & 498.680 \\
\hline & $* * 2000$ & 12,8 & 25,2 & 4,3 & 13,8 & 10.797 .411 & 951.510 \\
\hline & $* * 2001$ & 14,3 & 26,1 & 4,2 & 12,2 & 8.377 .666 & 659.486 \\
\hline & *1959 & $\ldots$ & 32,5 & 4,6 & 2,0 & $<100$ & $<100$ \\
\hline & *1970 & $\ldots$ & 25,22 & 7,9 & $\ldots$ & 40.000 & $\ldots$ \\
\hline & *1978 & $\ldots$ & 27,6 & 9,4 & 8,23 & 96.000 & $\ldots$ \\
\hline & *1985 & $\ldots$ & 24,38 & 6,7 & 3,8 & 170.000 & 7.000 \\
\hline \multirow[t]{8}{*}{ Camorim } & **1996 & 15,4 & 25,8 & 4,6 & 2,2 & 117.496 .667 & 1.876 .967 \\
\hline & **1997 & 35,1 & 26,6 & 5,0 & 6,2 & 44.616 .667 & 8.946 .975 \\
\hline & **1998 & 36,6 & 26,8 & 4,9 & 2,2 & 2.838 .333 & 105.833 \\
\hline & **1999 & 31,7 & 25,1 & 3,5 & 5,0 & 5.843 .333 & 626.917 \\
\hline & $* * 2000$ & 23,3 & 26,0 & 2,2 & 5,6 & 2.909 .667 & 526.833 \\
\hline & $* * 2001$ & 12,8 & 25,8 & 3,4 & 5,2 & 4.775 .000 & 202.500 \\
\hline & $* * * 2004$ & 104,3 & 28,0 & 7,7 & 5,95 & $\ldots$ & $\ldots$ \\
\hline & $* * * * 2005$ & 90 & 29,2 & 5,3 & 9,69 & $\ldots$ & $\ldots$ \\
\hline Limites & & $\ldots$ & $\ldots$ & $>5,0$ & $0,5-30$ & $<5.000$ & $<1.000$ \\
\hline
\end{tabular}

Fonte: Modificado de *ZEE, 1993; **IPP, 2001a; *** $* * * *$ CARVALHO HOSKEN SA, 2004, e 2005. 
11. Segundo Lima-e-Silva et al (1999, p. 106), eutrofização é o processo de enriquecimento das águas por nutrientes que alimentam o crescimento vegetal.

12. A gigoga é uma planta aquática que se alimenta de nutrientes encontrados nos esgotos domésticos, por isso, quanto mais poluída a água maior sua velocidade de reprodução; é uma planta típica de água doce, que não suporta salinidade elevada e morre em contato com a água do mar.

13. PT se refere a Fósforo Total e NT, a Nitrogênio Total. A classificação das lagoas se baseia nos limites definidos pela OECD (Organization for Economic Cooperation and Development), 1982
A taxa de Oxigênio Dissolvido (OD), por exemplo, se mostra abaixo da mínima ( $5 \mathrm{mg} / \mathrm{L}$ ); isso se deve, principalmente, aos despejos de origem orgânica, comprometendo a saúde de seres aquáticos aeróbios, daí a mortandade de peixes, em determinados períodos do ano. Os índices de coliformes totais e de coliformes fecais ( $E$. Coli) confirmam a presença de microorganismos patogênicos nessas águas. Analisando a Lagoa da Tijuca, verifica-se a piora desses índices.

A Lagoa da Tijuca é a mais comprometida das lagoas da região, no que concerne à qualidade das águas. Se até a década de 80 a profundidade da lagoa alcançava dois metros, hoje chega a atingir apenas 10 centímetros, em algumas áreas em dadas épocas do ano (PORTELLA, 2001). Isso ocorre, principalmente, devido ao lançamento de esgoto sem tratamento preliminar que contribui para acelerar o processo de eutrofização natural da lagoa, levando ao estado de hipertrofização (Tabela 8). ${ }^{11}$ O esgoto é despejado in natura na água e é acumulado no fundo da lagoa, causando assoreamento e liberando grande quantidade de fósforo e nitrogênio, que servem de nutrientes para o crescimento de plantas aquáticas, como as gigogas (HOUGH, 2000). ${ }^{12}$

Tabela 8. Eutrofização nas lagoas da Barra da Tijuca. ${ }^{13}$

\begin{tabular}{|c|c|c|c|c|}
\hline Lagoas & PT ( g/L) & NT $(\mathrm{g} / \mathrm{L})$ & Estado & Características do Estado \\
\hline Marapendi & 210 & 1670 & \multirow[t]{2}{*}{ Eutrófico } & \multirow{2}{*}{$\begin{array}{l}\text { Lagoas verdes e com lodo, com grande } \\
\text { quantidade de nutrientes e algas. }\end{array}$} \\
\hline Lagoinha & 310 & 1070 & & \\
\hline Tijuca e Camorim & 490 & 4230 & \multirow[t]{2}{*}{ Hipertrófico } & \multirow{2}{*}{$\begin{array}{l}\text { Lagoas férteis e supersaturadas em fósforo e } \\
\text { nitrogênio. Ela tem excessivo crescimento de } \\
\text { fitoplâncton que contribui para aumentar a } \\
\text { turbidade de água, empobrecer a } \\
\text { sustentabilidade para usos recreativos e } \\
\text { restringir o habitat para o consumo de peixes. }\end{array}$} \\
\hline Jacarepaguá & 680 & 4730 & & \\
\hline
\end{tabular}

Fonte: SEMADS, 2001

14. Valor referente ao mês de outubro de 2002, representando o pior índice de outubro a dezembro do mesmo ano.
Com isso a lâmina d'água da lagoa vem sendo reduzida, bem como sua profundidade, sofrendo, portanto, um processo de assoreamento. Conforme Hough (2000), a taxa média de sedimentação natural deve ser de um milímetro (1 mm) ao ano. Portanto, considerando-se que em algumas áreas da Lagoa de Camorim a profundidade média de dois metros $(200 \mathrm{~cm})$, até 1980 , reduziu para 10 cm em 2000 (PORTELLA, 2001), é evidente que a sedimentação nessa lagoa, que é dez vezes maior que o recomendado, não é natural. O problema de assoreamento que ocorre nas lagoas da região tem sido registrado por algumas instituições. Por exemplo, um estudo batimétrico do Conselho Regional de Engenharia, Arquitetura e Agronomia do Estado do Rio de Janeiro identificou as áreas de assoreamento do complexo lagunar da região e revelou a crítica situação de degradação ambiental da Lagoa da Tijuca. A maior parte do espelho d'água da lagoa atinge profundidade inferior a um metro (1 m), sendo a mínima de 0,30 m e a máxima de 12,7 m (CREA-RJ, 2000, Figura 9). Em 2002, um estudo da Secretaria Municipal de Meio Ambiente, responsável pelo monitoramento das águas das lagoas do Município, caracterizou o Arroio Pavuna e o Arroio Fundo como as principais fontes de poluição do sistema lagunar da região. Os canais se localizam na Lagoa do Camorim, poluindo principalmente as lagoas adjacentes, sendo Jacarepaguá e Tijuca. Na área próxima ao Arroio Pavuna, os índices de E.Coli foram os mais elevados do município, atingindo 160.000.000 NMP/100mL14, contra o limite máximo para condições de balneabilidade de 800 NMP/100mL (CONAMA, 1986). Por isso, nessa mesma área, a taxa de OD chegou a zero mg/L, quando o mínimo seria 5 mg/L (SMAC, 2002; CONAMA, 1986). Na Lagoa da Tijuca, a área do Saco Grande apresentou 1 mg/L para essa mesma 


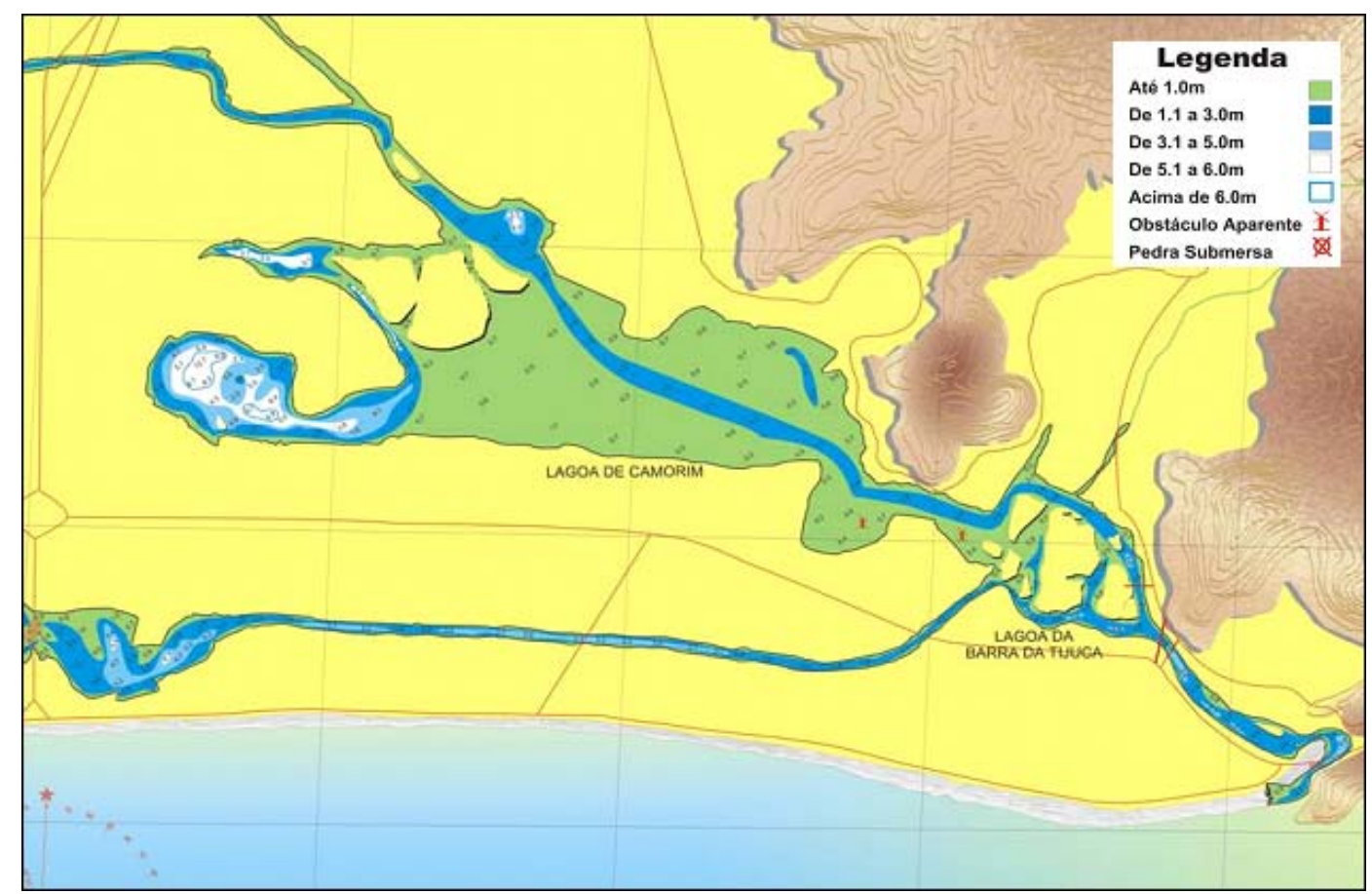

Figura 9: Batimetria da Lagoa da Tijuca e da Lagoa de Camorim. Fonte: Modificado de CREA, 2000 taxa. A lagoa também revelou elevados índices de DBO, atingindo 253 mg/L contra o limite máximo para condições de balneabilidade de $5 \mathrm{mg} / \mathrm{L}$ (SMAC, 2002; CONAMA, 1986). Assim, a poluição hídrica, que leva à eutrofização e ao assoreamento, e o desmatamento das faixas marginais da Lagoa da Tijuca e da Lagoa de Camorim, contribuem para a diminuição do espelho d'água das referidas lagoas. Os sucessivos aterros irregulares, juntamente com o processo de assoreamento das lagoas, fazem com que a área de superfície d'água seja reduzida. Por exemplo, de 1975 a 1993, houve a redução de 4\% do espelho d'água $\left(\mathrm{m}^{2}\right)$ na Lagoa da Tijuca, incluindo Saco e Saquinho (ZEE, 2002).

\section{Considerações Finais}

O processo de desenvolvimento urbano da Região da Barra da Tijuca (XXIV RA), no Município do Rio de Janeiro, a partir dos anos 70, promoveu diversos impactos e problemas ambientais, que emergiram sobremaneira pela ausência de uma política pública de gestão e de planejamento urbanos pautados por uma visão holística que relaciona as di- mensões econômica, física, e social, ao meio ambiente. Assim, diante do histórico de evolução urbana da região, podem ser analisados alguns aspectos. Primeiro, o modelo de urbanização implantado na região, tendo em vista as atividades do capital público e privado, não a reconheceu como ecossistema urbano onde interagem diversos sistemas, tais qual: urbano, natural, social, econômico,etc. Ou seja, o Estado ao ter investido nos componentes de infra-estrutura mais essenciais à urbanização (ex.: implantação e calçamento de vias, iluminação pública, coleta de lixo, abastecimento de água e provisão de energia elétrica e gás) priorizou apenas a dimensão urbana da cidade. Ao contrário, quando não implantou o componente esgotamento sanitário, a partir da adoção de um sistema em rede para a coleta, o tratamento e o destino final de esgotos, o Poder Público não priorizou a dimensão natural da cidade para a manutenção da qualidade do meio ambiente; provocando o surgimento de inúmeros problemas ambientais, dos quais o principal é a poluição dos corpos hídricos do Complexo Lagunar da Baixada de Jacarepaguá. 
Segundo, ainda sobre o sistema natural da cidade, na Barra da Tijuca, as formas naturais foram percebidas, e sobretudo exploradas pelo marketing imobiliário, somente por seus valores estéticos, como elementos isolados ou desconectados dos demais processos, o que resultou na utilização ineficiente dos recursos naturais. Terceiro, os parâmetros de intervenção urbana na região preconizavam e ainda preconizam, notadamente, o sistema econômico, a partir a valorização do preço da terra em benefício dos agentes imobiliários. De fato, o capital privado, cujas ações visam principalmente à rentabilidade, utiliza o planejamento urbano, nesse caso o Plano Piloto de Lucio Costa, de 1969, e principalmente suas posteriores modificações consentidas pela administração pública, para atender aos interesses das grandes empresas imobiliárias (SILVA, 2004). Isto é, a especulação fundiária surge como o principal elemento balizador do modelo de ocupação urbana implantado na Barra da Tijuca, onde o desenvolvimento econômico tornou-se uma referência obrigatória na ação pública, em detrimento de ações que permitissem o desenvolvimento sustentável. Conseqüentemente, esses fatores contribuíram, direta ou indiretamente, para o surgimento de: (i) impactos ambientais urbanos (tais qual a alteração da paisagem, a modificação do uso do solo, o incremento econômico de atividades comerciais e de serviço, entre outros); (ii) problemas ambientais (como o assoreamento, a redução das faixas marginais, a degradação gradativa das áreas de manguezal, a poluição das águas, a mortandade de peixes, a proliferação de plantas aquáticas,

15. Sobre os problemas ambientais na Barra da Tijuca, ver: SILVA, Gabriela da Costa. Problemas Ambientais Resultantes do Processo de Ocupação da Barra da Tijuca, no Município do Rio de Janeiro. Revista Brasileira de Direito Ambiental - Doutrina e Jurisprudência. São Paulo: Fiúza Editores, ano 1, n. 2, abr/jun 2005.

Enfim, as políticas públicas de gestão das cidades, a exemplo da região da Barra da Tijuca, freqüentemente, atuam numa intervenção pontual que não pressupõe a conexão entre os diversos sistemas da cidade. Então, ora investe-se em sistemas viários ou em infra-estrutura de saneamento, ora em pro- damentais da sustentabilidade ambiental em área urbana, capaz de viabilizar o avanço socioeconômico e a melhoria da qualidade ambiental não apenas das Lagoas da Tijuca e de Camorim, mas principalmente de todo Complexo Lagunar da Baixada de Jacarepaguá.

\section{Referências}

ADEMI-RJ, Associação de Dirigentes de Empresas do Mercado Imobiliário. Pesquisa ADEMI do mercado imobiliário: Análise do segundo semestre de 2003. Rio de Janeiro, ADEMI - Departamento de Pesquisa, 8p, 2004

CARDOSO, Adauto Lucio. Maneiras de pensar o urbanismo: questões teórico-metodológicas. In: Encontro da ANPUR. Anais... Águas de São Pedro, ANPUR, v. 2, p.8-34, 1989.

CARVALHO HOSKEN S. A ENGENHARIA E CONSTRUÇÕES. Monitoramento Ambiental do Processo de Dragagem na Lagoa da Tijuca. Rio de Janeiro, CARVALHO HOSKEN S. A., 2004. 30 p. (Relatório $\mathrm{N}^{\circ}$ 04/04).

CARVALHO HOSKEN S. A Engenharia e Construções. Monitoramento Ambiental do Processo de Dragagem na Lagoa da Tijuca. Rio de Janeiro: CARVALHO HOSKEN S. A., 2005. 21 p. (Relatório No 09/05)

CECA, Comissão Estadual de Controle Ambiental. Deliberação n 1078 de 25 de junho de 1987. Rio de Janeiro: CECA, 1987.

CMMAD, Comissão Mundial sobre Meio Ambiente e Desenvolvimento. Nosso Futuro Comum. Rio de Janeiro, FGV, 1991. 430 p.

COELHO, Maria Célia Nunes. Impactos Ambientais em Áreas Urbanas - Teorias, Conceitos e Métodos de Pesquisa. In: GUERRA, Antônio José Teixeira; CUNHA, Sandra Baptista (organizadores). Impactos Ambientais Urbanos no Brasil. Rio de Janeiro: Bertrand Brasil, 2001. Cap.1, p. 19-45. jetos de embelezamento paisagístico, contudo, sem potencializar a interface existente entre esses. Para minimizar os diversos impactos e problemas ambientais anteriormente identificados é importante, sobretudo, entender o ecossistema urbano como conjunto de sistemas que se engendram formando uma malha invisível e indivisível. Nesse sentido, cabe repensar o atual modelo de desenvolvimento urbano da região segundo os pressupostos fun-
CONAMA, Conselho Nacional do Meio Ambiente. Resolução CONAMA N ${ }^{\circ} 20$, In: , Resoluções do CONAMA; 1984/86, p. 81-83. Brasília, SEMA, 1986.

CORRÊA, Roberto Lobato. O Espaço Urbano. Rio de Janeiro, Ática, 2002. 94 p.

GOVERNO do Estado do Rio de Janeiro. Edital de "concessão pública para serviços de operação dos sistemas de abastecimento de água, de coleta e tratamento de esgoto na Baixada de Jacarepaguá, Barra da Tijuca e Recreio dos Bandeirantes". Rio de Janeiro, 74p, 2000.

COSTA, Lucio. Plano Piloto para a urbanização da baiPontal da Sernambetiba e Jacarepaguá. Guanabara: Agência Jornalística Image, 1969. $16 \mathrm{p}$. xada compreendida entre a Barra da Tijuca, o 
CREA-RJ, Conselho Regional de Engenharia e Arquitetura. Carta Náutica do Sistema Lagunar Barra/ Jacarepaguá. Rio de Janeiro, CREA-RJ, 2000.

EVANGELISTA, Helio de Araújo. Uma abordagem geográfica à reivindicação por equipamento sanitário. 1989. 135 p. Dissertação (Mestrado). Programa de Pós-Graduação em Geografia, Universidade Federal do Rio de Janeiro, Rio de Janeiro.

FOLADORI, Guilhermo. Limites do desenvolvimento sustentável. São Paulo: Editora da Unicamp, 2001. $221 p$.

HARDOY, Jorge E.; MITLIN:Diana; SATTERTHWAITE, David. Environmental Problems in Third World Cities. Londres, Earthscan Publications, 1992. 464p.

HOUGH, Michael. Cities and Natural Process. Londres, Routledge, 2000. 319 p.

HOUGH, Michael. Design with city nature, an overview of some issues. Londres, Routledge, 1990.

IBGE, Instituto Brasileiro de Geografia e Estatística. Censo Demográfico 1991; Contagem da População 1996; e Agregado de Setores de Sinopse preliminar do Censo Demográfico 2000. Disponível em: <http://www.ibge.gov.br>. Acesso em: 05 mar. 2006

IPLANRIO, Empresa Municipal de Informática S. A.; ACOABR, Assistência Comunitária aos Assentamentos de Baixa Renda do Município do Rio de Janeiro. Cadastramento de Assentamentos de Baixa Renda. Rio de Janeiro, IPLANRIO/ ACOABR, 1993.

IPP, Instituto Municipal de Urbanismo Pereira Passos. Anuário Estatístico da Cidade do Rio de Janeiro 95-97. Rio de Janeiro: IPP. CD ROM. 1997.

IPP, Instituto Municipal de Urbanismo Pereira Passos. Condições físico-químicas e bateriológicas da Lagoa Rodrigo de Freitas e das lagoas do Complexo Lagunar de Jacarepaguá, por ano, segundo os pontos de coleta - 1996/2001. Rio de Janeiro: IPP 2001a. (Armazém de Dados / Indicadores Ambientais).

IPP, Instituto Municipal de Urbanismo Pereira Passos. Domicílios, população residente em favelas (Setores Censitários - Aglomerados Subnormais) e densidade domiciliar, segundo as Áreas de Planejamento, Regiões Administrativas - 1991/1996/2000. Rio de Janeiro: IPP, 2001b. (Armazém de Dados / Características Demográficas).

IPP, Instituto Municipal de Urbanismo Pereira Passos. Imóveis residenciais, comerciais e indústrias, por tipologia e faixas de área construída, segundo as Áreas de Planejamento, Regiões Administrativas e Bairros - 2000. Rio de Janeiro: IPP, 2001c. (Armazém de Dados/ Ambiente Construído).

IPP, Instituto Municipal de Urbanismo Pereira Passos. Índice de Desenvolvimento Humano Municipal (IDH), por ordem de IDH, segundo as Regiões Administrativas - 2000. Rio de Janeiro: IPP, 2001d (Armazém de Dados / Índice de Desenvolvimento Humano Municipal - IDH)

IPP, Instituto Municipal de Urbanismo Pereira Passos. Mapa da Região da Barra da Tijuca - RA XXIV. Disponível em: http://portalgeo.rio.rj.gov.br/ bairroscariocas/mapasefotos/imagem_ra24.jpg. Acesso em: 12. dez. 2006. (Armazém de Dados/ Bairros (ariocas).

IPP, Instituto Municipal de Urbanismo Pereira Passos. Notas Técnicas do Plano Estratégico 2001/2004 Campo Grande, Grande Méier e Barra da Tijuca (nos 2, 3 e 4). Rio de Janeiro: IPP, 2003. 16 p. (Coleção Estudos da Cidade, n. 94).

IPP, Instituto Municipal de Urbanismo Pereira Passos. Favelas de Angu Duro, Cambalacho e Muzema. Rio de Janeiro: IPP, 2002. (Memória Iconográfica Favelas e Loteamentos).

IPP, Instituto Municipal de Urbanismo Pereira Passos. População residente, área territorial e densidade demográfica, segundo as Áreas de Planejamento, Regiões Administrativas e Bairros - 1960/1996 e 2000. Rio de Janeiro: IPP, 2001e. (Armazém de Dados/ Características Demográficas)

LEITÃO, Gerônimo. A construção do eldorado urbano, o plano piloto da Barra da Tijuca, Baixada de Jacarepaguá 1970/1986. Rio de Janeiro, UFF, 1995. $132 \mathrm{p}$.

LYNCH, Kevin. Good city form. Cambridge, The MIT Press, 1989. 514p.

LYNCH, Kevin. The Image of the City. Cambridge, The MIT Press, 1995. 187p.

MAGRINI, Alessandra. A avaliação de impactos ambientais. In: MARGULIS, Sergio. Meio Ambiente: aspectos técnicos e econômicos. Rio de Janeiro, IPEA: Brasília, IPEA/PNUD, Cap. 4. p. 85-108, 1990.

MEINIG, D. W. The Beholding Eye: Ten Visions of the Same Scene. In: __. The interpretation of ordinary landscapes. Geographical Essays. New York: Oxford University Press, 1979. 255p.

MOTA, Suetônio. Urbanização e meio ambiente. Rio de Janeiro: ABES, Cap. 3, p. 36-81 1999

PORTELLA, L. Areia toma conta de lagoa na Barra. Jornal do Brasil, Rio de Janeiro, 01 nov. 2001. Disponível em http,//www.jbonline.terra.com.br/jb/ papel/cidade. Acesso em, 31 out. 2001

RODRIGUES, Alexandre Corrêa. Da lama ao caos: diagnóstico dos impactos ambientais provocados pela poluição por efluentes domésticos na lagoa de Marapendi (Barra da Tijuca - RJ). 2000. 59p. Monografia (Graduação). Departamento de Geografia, Universidade Federal do Rio de Janeiro, Rio de Janeiro.

ROGERS, Richard; Gumuchdjan, Philip (Org.). A Cultura das cidades; Cidades sustentáveis. In:._. Cidades para um pequeno planeta. Barcelona: Gustavo Gilli, 2001. Cap. 1 e 2, p. 1-64.

SACHS, Ignacy. Estratégias de transição para o século XXI. São Paulo, Nobel, 1993. 103 p.

SANTIAGO, Alaôr, 2004. Comunicação pessoal.

SEMADS, Secretaria Estadual de Meio Ambiente e Desenvolvimento Sustentável. Ambiente das águas do Estado do Rio de Janeiro. Rio de Janeiro: Sholna Reproduções Gráficas, 2001. 230 p. 
SILVA, Gabriela da Costa. Crescimento vertical da favela Rio das Pedras. 2004. 1 fotografia, color., original $10 \mathrm{~cm} \times 15 \mathrm{~cm}$.

SILVA, Gabriela da Costa. Impactos Ambientais Resultantes do Processo de Ocupação Urbana na Baixada de Jacarepaguá, 284p. Dissertação (Mestrado em Urbanismo) Programa de Pós-graduação em Urbanismo, Universidade Federal do Rio de Janeiro, Rio de Janeiro, 2004.

SOUZA, Marcelo Lopes de. O desafio metropolitano: um estudo sobre a problemática sócio-espacial nas metrópoles brasileiras. Rio de Janeiro: Bertrand Brasil, 2000. 368p

SMAC, Secretaria Municipal de Meio Ambiente. Mapeamento e caraterização do uso das terras e cobertura vegetal no Município do Rio de Janeiro entre os anos de 1984 e 1999. Rio de Janeiro: SMAC, 2000. 75 p.

SMAC, Secretaria Municipal de Meio Ambiente. Qualidade Ambiental - Primavera, Verão, Outono 2002. Rio de Janeiro, SMAC, 2002.

SPIRN, Ann Whiston. O Jardim de Granito, Natureza Urbana e Desenho Humano. São Paulo, EDUSP, 1995
VIANNA, Aurélio; MENEZES, Lais; IÓRIO, Maria Cecília; RIBEIRO, Vera Massagão (organizadores). Educação ambiental, uma abordagem pedagógica dos temas da atualidade. Rio de Janeiro, CEDI/CRAB, 1994. $88 \mathrm{p}$.

VILA do Pan tenta o Guinness. O Globo, 05 fev. 2006. <http://www.sinduscon-rio.com.br/sindusletter/ sindusletter 080206/n6.htm>. Acesso em: 09 mar. 2006. $2006^{\mathrm{a}}$

VILA Pan-Americana: um marco histórico no mercado imobiliário do Rio de Janeiro. CRECI-RJ, Conselho Regional de Corretores de Imóveis do Estado do Rio de Janeiro. <http://www.creci-rj.org.br/stand/ pagina7.htm>. Acesso em: 10 mar. 2006. 2006b.

ZEE, David Man Wai. Diagnóstico do Aporte de Afluentes Domésticos do Canal a Joatinga na Praia da Barra da Tijuca - Município do Rio de Janeiro. 2002. 167 p. Tese (Doutorado). Programa de Pós-Graduação em Geografia, Universidade Federal do Rio de Janeiro, Rio de Janeiro.

ZEE, D. M. W. et al. Estudo Ambiental, Faixa Margina da Lagoa da Tijuca. Rio de Janeiro, UERJ, 1993. Publicação Restrita. 108 p. 


\title{
(In)Sustentabilidade Ambiental na Ocupação Urbana da Barra da Tijuca, na Cidade do Rio de Janeiro
}

\section{Gabriela da Costa Silva}

\begin{abstract}
The historic of the urban occupation in Barra da Tijuca, in Rio de Janeiro City, since the 70's, reveals that the region appears as an icon for huge investments of public and particular capital, achieving important social economical development. However, it is noticeable that the guidelines to this remarkable urban expansion are based, in especial, on the interests of important real state agencies that, based on the local and regional governments, aim to enhance over profit standards even if urban environmental quality is damaged, restricting the possibilities of sustainable urban development. Notoriously, the absence of a region sewer system to collect and treat the domestic effluents contributes to cause environmental impacts and problems in the Lagunar Complex of Jacarepaguá Lowlands, mainly in Lagoons Tijuca and Camorim.
\end{abstract}

Key Words: Urban Sustainability, Environmental Problems, Environmental Impacts. 